\title{
STACKED SILICIFIED BURROW NETWORKS OF THE LOWER PERMIAN BARNESTON LIMESTONE OF KANSAS: A RECORD OF EPISODIC CARBONATE SEDIMENTATION
}

\author{
MILLER, Keith B., 108 Thompson Hall, Department of Geology, Kansas State \\ University, Manhattan, KS 66506-3201, U.S.A.
}

The Midwest floods of 1993 resulted in the erosion of the Milford Lake spillway in northeastern Kansas, exposing the entire Barneston Limestone. The Barneston is the thickest (22 meters) carbonate unit within the Permian section of Kansas, and is the most prominent cliff-former in the Flint Hills Physiographic Province. The Florence Limestone Member, comprising the lower 10.5 meters of the Barneston, contains closely-spaced nodular chert layers in a skeletal wackestone to packstone. It is the faunally most diverse member and dominated by brachiopods, fenestrate, ramose and encrusting bryozoans, crinoids, and echinoids. Above the Florence the Barneston becomes less fossiliferous and more dolomitic. A variety of sedimentologic features, including laminated dolomitic mudstone, abundant gypsum rosette molds, polygonal desiccation cracks, tepee structures and boxwork structures, strongly suggest upward shallowing and the development of evaporitic sabkha conditions.

Erosion by the floodwater of 1993 exposed the numerous chert layers of the Florence in relief on extensive bedding plane surfaces, enabling their three dimensional geometry to be easily examined for the first time. The morphology of the nodular chert layers resembles that of complex burrow systems similar to Thalassinoides. On many surfaces they are joined to form continuous polygonal networks. Commonly, two or more of the chert layers are joined by vertical and inclined chert masses to form multistoried networks. The apparent localization of silica replacement within burrows may have been a result of higher porosity and permeability within the skeletal burrow fills. Unsilicified Rhizocorallium and some Thalassinoides-like burrow systems occur in a few beds. These burrow systems are filled with skeletal debris coarser than the matrix and are probably similar in origin to the "tubular tempestites" described from modern shallow marine environments.

Vertically connected nodular chert layers form multi-storied galleries that are consistently 20 to $30 \mathrm{~cm}$ thick. These galleries are stacked, and although typically separated by less than $10 \mathrm{~cm}$, do not appear to be interconnected. This would seem to suggest relatively rapid sediment aggradation followed by the development of extensive burrow networks. Filling of pre-existing burrow networks by skeletal debris may have accompanied these sedimentation events. The stacked silicified burrow networks are in turn organized into meter-scale cycles that are separated by clayey units of a few tens of centimeters or less. These cycles can be traced for at least several tens of kilometers along the outcrop. Based on previous work on Lower Permian cyclicity, these meterscale cycles may record climatic fluctuations in which clean limestones record arid or semi-arid conditions, and the clay-rich carbonates record somewhat wetter climates when terrigenous clastics were flushed into the basin. 